HOW

Volume 29, Number 1, pages 154 - 172

https://doi.org/10.19183/how.29.1.614

\title{
Effect of Backward Summary Technique on Reading Comprehension Enhancement among Non-English Majors
}

\author{
Efecto de la Técnica de Resumen Hacia Atrás en la Mejora de la \\ Comprensión Lectora entre Estudiantes que no Hablan Inglés
}

\author{
Samaneh Bahrami ${ }^{1}$ \\ Ramin Rahimy ${ }^{2}$ \\ Islamic Azad University, Tonekabon, Iran
}

\begin{abstract}
This study aimed to probe whether using the backward summary technique led to reading comprehension enhancement among non-English major university students at the Islamic Azad University of Babol, located in Babol city, in the North of Iran. 120 B.S. level nursing and microbiology students were randomly selected from a population of non-English majors enrolled for the General English course, divided into four groups of 30, and were randomly assigned to two experimental and two control groups. A pre-test of reading comprehension was administered to all groups, and then, they were taught passages to read for eight sessions but with different methods. A one-way ANCOVA was run to investigate the impact of the intervention, while controlling for the pre-test. The results indicated statistically significant effects for the experimental groups on the post-test, regarding comprehension, retention, and organization of the key concepts.

Keywords: academic reading comprehension, backward summary, reading strategies, schema theory, summarization
\end{abstract}

She is a Ph.D. candidate and an academic staff member of Islamic Azad University. Her main research interests include ESP, reading comprehension enhancement, and SLA.

samaneh.bahrami@gmail.com

ORCID ID: https://orcid.org/0000-0002-9433-7370

2 He is an assistant professor of Islamic Azad University of Tonekabon. His main research areas include ESP, material development, SLA and translation.

drraminrahimy@toniau.ac.ir

ORCID ID: https://orcid.org/0000-0002-0859-7812

Received: September 29th, 2020. Accepted: October 22nd, 2021.

This article is licensed under a Creative Commons Attribution-Non-Commercial-No-Derivatives 4.0 International License. License Deed can be consulted at https://creativecommons.org/licenses/by-nc-nd/4.0. 


\section{Resumen}

El objetivo del estudio fue probar si el uso de la técnica de resumen hacia atrás conduce a una mejora de la comprensión lectora entre estudiantes universitarios que no hablan inglés en la ciudad de Babol en el norte de Irán. Los 120 estudiantes de enfermería y microbiología de licenciatura en ciencias se seleccionaron aleatoriamente de una población de estudiantes de especialización no inglesa inscritos en el curso de inglés general, divididos en cuatro grupos de 30 estudiantes cada uno y asignados aleatoriamente a dos grupos experimentales y dos de control. Se administró un pretest de comprensión lectora a todos los grupos, luego se les entregó unos pasajes para leer durante ocho sesiones pero con diferentes métodos. Se ejecutó un ANCOVA unidireccional para investigar el impacto de la intervención, mientras se controlaba la prueba previa. Los resultados indicaron efectos estadísticamente significativos para los grupos experimentales en el pos-test, en cuanto a comprensión, retención y organización de los conceptos clave.

Palabras clave: comprensión lectora académica, resumen al revés, estrategias de lectura, teoría de esquemas, resumen

\section{Introduction}

Reading comprehension skill plays a key role in learning a foreign language. Nevertheless, it is a great challenge to gain competence in foreign language (FL) reading due to readers' proficiency level, text type and difficulty, and task demands (Alderson, 2000). Unfortunately, many university students, especially in non-English majors, have problems with comprehending what they read in English as a foreign language because they get to higher education level unprepared for the demanding reading tasks expected from them.

Since English is learned as a foreign language in Iran, many Iranian university students rarely speak it in their daily lives. Nevertheless, a good command of reading comprehension skill is essential for them to gain academic achievements. That is why the ability to comprehend academic English texts has an overriding importance to Iranian university students, especially non-English majors (Tarshaei \& Karbalaei, 2015; Zahedi \& Tabatabaei, 2015). In recent years, the need for good reading comprehension has steadily incremented, and the demands on university students to read effectively is higher since they have to read complicated technical texts related to their fields of study mostly in English. Hence, the need for focusing on comprehension fostering strategies and techniques is urgent. Most of these students struggle in learning to read and understanding what is read. The ultimate goal of academic reading courses should be assisting students to read fluently and independently with good comprehension, which is the base of all meaningful learning.

Despite the large body of research on summarization, few studies have investigated the effects of summery strategy instruction on Iranian university students' reading comprehension enhancement. Although Baleghizadeh and Babapur (2011) and Shokrpour, Sadeghi, and Seddigh (2013) conducted their studies with Iranian university students and had positive 
findings, as Chiu (2015) indicated, "neither study explained in detail how summarization was taught, nor were the differences between the treatments for the experimental and control groups made clear. Lack of such information makes the interpretation of the results less clear" (p. 81). Merging reading and writing instructionally is a complicated process, specifically in an EFL context (Hirvela, 2016). Consequently, there is an urgent need for designing experiments that show how to do that most productively. The current study was an attempt to fill these gaps in the existing literature.

Inspired by Wormeli's (2005) views on diversity and flexibility of summarization techniques, backward summary refers to combination of pre-reading questions and mapping activity at the pre-reading stage with the aim of activating students' background knowledge, asking their personal opinions about the topic, and encouraging them to guess and form hypotheses based on the text clues, such as the title and key words. In fact, the term backward suggests that a brief summary in the form of a visual outline is completed before reading the passage. In other words, the term refers to the reverse order of forming a visual outline before reading the whole passage in detail.

Based on the already-mentioned points, the current study probed the effectiveness of backward summary technique on reading comprehension enhancement among Iranian university students. The following research questions were proposed:

- $\mathrm{Q}_{1}$ : Does backward summary technique boost English reading comprehension among Iranian microbiology candidates at B.S. Level?

- $\mathrm{Q}_{2}$ : Does backward summary technique boost English reading comprehension among Iranian nursing candidates at B.S. Level?

\section{Literature Review}

Reading comprehension is a demanding dynamic and cognitive process. Even being proficient readers and users of comprehension strategies like guessing the meaning of complicated, technical, or unfamiliar words from the context, summarizing the read material for assisting retention and forming mental maps for organizing main ideas in L1 does not

156 guarantee that students can successfully apply all the necessary strategies while reading in an FL context. Consequently, strategy instruction should be at the heart of any successful and mindful pedagogical enterprise, especially in the academia, regarding the length and nature of reading tasks in these contexts.

Mikulecky (2008) believes that reading strategy instruction enables the learners to communicate with the text, figure out the intended meaning of the author, and comprehend the key concepts of the text. In Wilhelm and Li's words, "for most language learners who 
are already literate in a previous language, reading comprehension is primarily a matter of developing appropriate and efficient comprehension strategies" (2008, p. 291).

Pressley (2006) assumes that strategic reading should be taught through explicit instruction to enhance learners' autonomy and self-awareness of the meaning constructing process, prepare students for academic reading performances, and motivate them to play an active role in their learning. Learners' previous information and cultural backgrounds should also be taken into consideration (Lin \& Chern, 2014).

Furthermore, reading is purposeful and requires an active involvement of the readers, as they have specific goals to achieve, when reading a text (Grabe, 2009; Grabe \& Stoller, 2011; Koda, 2005). Grabe (2009) assumes that 'teaching students effective strategies while trying to build main-idea comprehension of text and joining these two goals through scaffolded discussions around a text is... comprehension instruction" (p. 207).

Reading comprehension as a dynamic process requires active and meaningful communication between the author and the reader (Hellman, Blair, \& Ruply, 1998). However, it is the latter who is most likely to spoil the mutual enterprise by misunderstanding, not paying attention, or giving up reading. Consequently, readers have the key role in comprehending the read materials (Grabe, 2009).

Teachers should bear in mind that "reading occurs in a context, and the meaning of a text is derived from the previous knowledge stored in the reader's mind and the processes through which the reader tackles it" (Cook, 2008, p. 121). Schema theory relates to the interrelated and interdependent relationship between text comprehension and the readers' prior or background knowledge (Bernhardt, 2011; Pardo, 2004; Smith, 2004). It regards reading as an active event in which readers" prior knowledge is relevant to what is read to frame an ongoing transaction with the text, which leads to a unique understanding and interpretation of the read passage (Smith, 2004).

Research findings indicate that "deciphering information implies approaching a text from different perspectives" (Bogoya, 2011, p. 48). Graphical organizers (GOs) are "visual displays that teachers use to organize information to make [it] easier to understand and learn” (Meyen et al., 1996, p. 132). GOs not only help students generate mental images but also build graphic representations of the information they have read (Gallavan \& Kottler, 2007; Rumiris, 2014). GOs can be considered as an instructional tool to assist students to organize and categorize information at different phases of reading. For example, they can be used to build background knowledge, make predictions and form hypotheses or educated guesses during the pre-reading stage. They can also assist the students to explore the text purposefully to see if these guesses and predictions come true or need modification during while-reading stage, and boost information retention 
and recall at the post-reading stage in the form of mental maps or visual outlines including the key concepts.

GOs also enable the students to handle misunderstandings, self-monitor their comprehension, and foster discovery learning, which can contribute to comprehension enhancement (Bogoya, 2011; Meyen et al., 1996). Teachers should take into consideration the age, needs, interests, and FL proficiency levels of the learners and the diversity and flexibility of using GOs in empowering reading comprehension at all stages of reading. They can be viewed as powerful instructional tools for developing the skills of identifying main and supporting ideas by illustrating the relationship between key concepts and supporting details, familiarizing students with text structures and patterns, and organizing ideas for a better retention and recall of the read material in the form of charts, input tables, visual outlines, and concept maps.

Chiu (2015) refers to writing activities such as note-taking, answering post-reading questions, and summarizing, which mostly accompany reading for academic purposes. It can be said that if students can summarize well, they improve their reading ability (Lin \& Chern, 2014). According to Wormeli (2005), "summarization not only helps readers focus on the essential information in a text but it also promotes learning that lasts because students spend time reflecting and processing what they have read while summarizing the texts" (p. 6). Summarizing is beneficial to both the teachers and students. For the former, it provides evidence of the students' ability to select the gist of a text. Thus, it plays a role as "an informal indicator of comprehension" and reveals the students' "ability to prioritize and sequence the read texts" as well (Westby et al., 2010, p. 276). For the latter, it gives a good chance for communicating important points, checking understanding, and providing an opportunity "to practice decision making and sequencing" (Westby et al., 2010, p. 276).

Students should be trained and encouraged to use a bunch of comprehension strategies before, during, and after reading a text. It is assumed that they comprehend when they can predict what comes next, ask questions about what has been read, remember experiences related to the text, make mental representations of the passage, or link it to what is already known (Lin \& Chern, 2014; Khaki, 2014; Pressley, 2006). Bogoya (2011) assumes that 'students' training in strategies such as organizing information, understanding a paragraph, or summarizing key information is required if their reading is to be successful" (p. 48). Teaching students how to recognize meaningful information increases their motivations and interests in FL reading as well (Wormeli, 2005). Since source-based writings are frequently used in academia, emphasizing on instruction and the use of summarization techniques can enhance the interrelated reading-writing bond, which is an indispensable feature of academic competence, especially in the globalization era. 


\section{Method}

\section{Design and Participants}

A quasi-experimental pre-test and post-test with equivalent control-group design was used in this study. Table 1 shows the research design of the current study.

Table 1. Research Design

\begin{tabular}{|l|cc|c|}
\hline \multicolumn{1}{|c|}{ Group } & \multicolumn{2}{|c|}{ Pretest- Treatment } & Post-Test \\
\hline Experimental & $\mathrm{O}_{1}$ & $\mathrm{X}$ & $\mathrm{O}_{2}$ \\
\hline Control & $\mathrm{O}_{1}$ & - & $\mathrm{O}_{2}$ \\
\hline
\end{tabular}

$\mathrm{O}_{1}=$ Pre-test, $\mathrm{O}_{2}=$ Post-test, $\mathrm{x}=$ Treatment, $-=$ No treatment

As indicated in the above table, the current research had a quasi-experimental design with pre-test, pedagogical treatment, and post-test stages. It was part of a Ph.D. project, including two researchers and 120 participants. The researchers were both academic staff members of the Islamic Azad University. For the sake of the internal validity of the research, all the classes were taught by one of the researchers (the Ph.D. candidate) under the supervision of the other researcher (her thesis advisor).

A pool of 120 freshmen, including 60 nursing and 60 microbiology major undergraduate students, of the Islamic Azad University of Babol, participated in the current study in the North of Iran. They were all native Persian speakers of both genders, and their ages ranged from 18 to 24 years. They were selected for the study randomly from the population of nonEnglish major students who enrolled in the compulsory General English course at the time of the experiment. They were from four intact classes and were randomly assigned to two experimental and two control groups; each class contained 30 students. Due to administrative and time restrictions, using intact classes was the only choice for the researchers. All of the participants were high school graduates, having the experience of studying English for at least four years, and were pursuing a B.S. degree in nursing and microbiology.

\section{Materials and Instruments}

The reading materials were selected from the second edition of Reading for General English (2010), a course book for university students developed by SAMT, the organization for researching and composing university textbooks in the humanities in Iran. The textbook was designed to teach General English to non-English major students at the university level by a group of experienced university professors. The compulsory General English course 
prepares non-English majors for reading longer field-related expository texts in English for Specific Purpose courses.

The first eight lessons, consisting of short expository texts, were used for the study. Each passage was composed of five paragraphs. It included a list of pre-reading questions to familiarize the students with the topic before reading the passage and activating their previous related knowledge. There was a mapping activity in the form of an input table, asking the students to extract the relevant information for each key concept with the aim of providing the students with a visual outline of the text before careful and detailed reading of the whole passage.

For example, one of the texts was about circus animals and their trainers. For the prereading activity, the students were asked to name some circus animals and comment on the advantage or disadvantages of animal trainers' jobs. For the mapping activity, they were given key concepts like big cats and techniques for taming wild animals, and were asked to select and extract the relevant information and complete the input table before a detailed and careful reading of the entire passage. The first eight lessons of the book were as follows:

- Lesson 1: The Age of the Dinosaur

- Lesson 2: A World below Trees

- Lesson 3: Showtime

- Lesson 4: Life in the Sea

- Lesson 5: Rainbows

- Lesson 6: How Does Your Skin Grow?

- Lesson 7: From Tadpole to Frogs

- Lesson 8: Treasures from the Deep

A researcher-made multiple-choice test measured English reading comprehension to check whether the students could differentiate the main idea from supporting details, or irrelevant information, figure out the authors' purposes, and infer from the text-based information. The validity of the test was specified based on specialist opinions and its

160 reliability was measured by piloting it on 40 students with identical characteristics to the target samples. A reliability analysis was run on the reading comprehension test. Cronbach's alpha showed the test to reach acceptable reliability, $\alpha=0.86$, which was considered acceptable according to the criterion of 0.70 (Robson, 1993).

The test consisted of four passages from the textbook. Five multiple-choice questions followed each passage. In order to determine the entry behavior of all the participants, a reading comprehension test was administered as the pre-test. After the pedagogical 
treatment, the same test was given as the post-test to identify the students' gain regarding the implemented treatment.

\section{Procedure}

Before starting the experiment, the teacher held a meeting with each class, and told them about the research purpose, that is boosting reading comprehension. They were all assured that their identities and scores would be kept confidential, and the test scores would only be used for evaluating the probable effectiveness of the pedagogical intervention, not for judging them. The students were willing to improve their reading skills, so they eagerly agreed to participate in the study and were very cooperative.

Each unit started with the pre-reading questions for encouraging the students to activate their background knowledge, form expectations, and make informed guesses about the text they were going to read. They were supposed to read the questions and give their answers or opinions. They were also asked to guess about the topic of the passage and the main ideas related to that topic. They could give their answers in Farsi in case of not knowing the exact English words that they needed to express their opinions. The aim of answering pre-reading questions was to concentrate on what they already know or expect to read about the topic. Since it was a common course for all university students, the topics were not completely new or only related to a specific field of study; therefore, all the students could talk about their background knowledge and share what they already know.

The students were encouraged to share their opinions, expectations, or previous knowledge regarding the topic with the class- without the fear of not knowing the proper English words or making grammatical mistakes in sentence composition. They were assured that they would not face these problems after reading the text. Moreover, sharing opinions with the class could benefit the students who did not participate in this activity, due to shyness or fear of making mistakes in composing sentences, to activate their prior knowledge by getting some information from their peers about the text they were going to read.

After this brief introduction, all the students were asked to write down their expectations or predictions regarding the text based on the title, pre-reading discussions, and their previous knowledge about the topic. Around fifteen minutes were spent for the discussions based on the pre-reading activities, and ten minutes were given to the students to make a list of their expectations, guesses, and predictions about the text that they were about to read in class.

The next phase of the pre-reading stage included the mapping activity task. The students were asked to extract the related information from the passage and complete the table. It was similar to a puzzle completion task; all the pieces were put together to shape the big picture. Therefore, the complete table could serve as the visual outline of the whole text. The aim 
of completing this task ahead of reading the passage was to see if this reverse order, that is, first forming a brief summary and then moving towards reading the whole passage, could lead to a better understanding of the concepts and reading comprehension enhancement. In fact, the term backward summary was used for emphasizing this reverse order. The students could choose to work either alone or in pairs. They were also allowed to use the English to English dictionary or ask the teacher for explanations if they faced any problems. The time allotted to finish this task was fifteen minutes. After completing the outline and getting a picture of the gist of the text, it was time to read the passage itself.

Each paragraph was read by a volunteer. While listening to each paragraph, the students were told to focus on the topic sentence, identify the main and supporting ideas, and ignore redundant information. They were also asked to check their lists of predictions and expectations to see whether they were confirmed by the text information or needed modifications according to the passage. This way, the text was read paragraph by paragraph by the volunteers, and the other students followed by checking whether their predictions came true or needed modifications. They were also asked to write down the main idea and supporting details for each paragraph to form a concept map. The teacher helped the students with confusing words, phrases, or sentences.

After reading the whole passage, they read comprehension questions and shared the answers with the class. Finally, they were given fifteen minutes to write a brief summary of what they read. This follow-up writing activity served as the final episode of the reading comprehension. The procedure can be illustrated as follows:

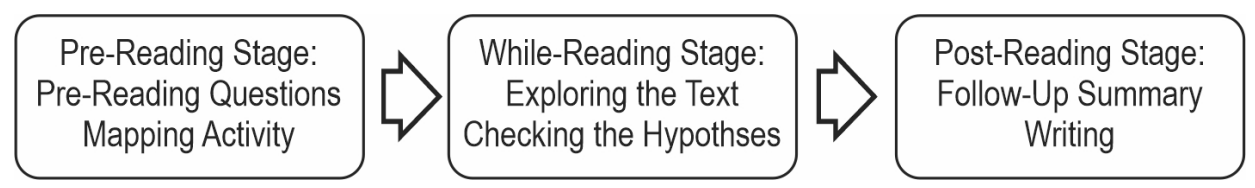

Figure 1. Summary of the Reading Comprehension Phases

162 In short, the students were first given a set of pre-reading questions to activate their background knowledge and make predictions about the text, followed by an input table to complete to get the gist of what they were about to read in the form of a visual outline. They were told to focus on the gist before going to more details. Then during the while-reading stage, they checked whether their expectations came true or needed modifications, which made the reading activity more interesting and purposeful, in the form of discovery learning. After reading the whole passage, they were told to write a brief summary about it. For summarizing the text, the students were told to review the visual outline, reread the original 
passage, focus on the main ideas, ignore unimportant or redundant parts, and avoid copying the exact words or sentences used in the original text. Thus, the follow-up summary writing activity could indicate the students' comprehension output from what they had already read. The time allotted to write the summaries was fifteen minutes. The teacher walked around and acted as a facilitator, helping the students who had any problems with wording or sentence formation.

The summaries were collected and read by the teacher. The papers were given to the students the following session together with the teacher's written comments and feedback. Fifteen minutes were allotted to read some of them in class. In order to avoid the risk of the students' discouragement and losing interest and motivation by getting low marks, the teacher gave her comments or suggestions on their written summaries, instead of directly correcting their mistakes and giving scores. General suggestions regarding selection, deletion, cohesion, and restatement were given to improve the form and content of the written summaries. In fact, the teacher's comments were an ongoing conversation with the students to foster their reading comprehension and composing skills.

Since the focus of the study was on reading comprehension enhancement, and the students practiced source-based writing tasks, all writing instruction was limited to how to write a brief summary of what had been read with putting emphasis on writing good topic sentences, paraphrasing, focusing on key concepts, and ignoring redundant information. Detailed writing instructions such as using conjunctive adverbs to form complex sentences and essay writing techniques were not discussed.

For the homework, the students were told to keep an English diary and jot down what they learned each session. They were encouraged to write freely without the fear of making grammatical mistakes or being judged by others. They were also told to go through the text that was read in class and make a list of all the new words that they learned in the passage. They were asked to make a list of all the new words they learned in each lesson. The pedagogical intervention went on for eight sessions, and each time the students gained more responsibility for doing the required tasks.

Finally, for the control groups, the familiar traditional method of reading a passage and doing comprehension check exercises like true or false and copying the exact words from the passage for answering the questions were used. For both the experimental and control groups, the instructional materials and learning content were the same except that the control groups were not exposed to summarization instruction. They were taught by the traditional teacher-centered reading approach in which the teacher directed the instruction and activities, initiated the questions, and students responded by copying the answers from the texts. The emphasis was on vocabulary teaching, analysis of grammatical structures of the texts and translation of the English text. 
Samaneh Bahrami,

Ramin Rahimy

\section{Data Analysis}

As the treatment was part of the regular compulsory General English course, the participants cooperated willingly, and all were present for the pre-test and post-test sections; therefore, no missing data were included. They were told to answer all items, so no question was left unanswered.

Furthermore, the threat that pre-test scores might influence the post-test scores was marginal because precautions were taken to avoid the practice effect. First, the correct answers were not revealed to the participants. Second, they were not allowed to take notes while taking the pre-test, and the exam papers were returned to the researcher immediately after the pre-test. Finally, the eight-week period was long enough for minimal recall of the pre-test content. The data collected from the pre-test and post-test were submitted for quantitative analyses.

The obtained data were analyzed via calculating a one-way ANCOVA (Analysis of Covariance) to investigate the impact of the pedagogical treatment while controlling for the pre-test, using SPSS 20. Preliminary checks were completed to be sure that all the assumptions of ANCOVA, including the normality of data, correlation between the covariate and dependent variable and homogeneity of the groups were met before running the ANCOVA.

\section{Results}

A one-way ANCOVA was run to examine whether reading comprehension scores differed between the microbiology major experimental and control groups, while controlling for post-test. Table 2 illustrates the results of ANCOVA for the two microbiology groups.

Table 2. ANCOVA Results for Microbiology Groups

\begin{tabular}{|l|c|c|c|c|c|c|}
\hline \multicolumn{1}{|c|}{ Source } & $\begin{array}{c}\text { Type III Sum of } \\
\text { Squares }\end{array}$ & df & $\begin{array}{c}\text { Mean } \\
\text { Square }\end{array}$ & F & Sig. & $\begin{array}{c}\text { Partial Eta } \\
\text { Squared }\end{array}$ \\
\hline Corrected Model & $83.360 \mathrm{a}$ & 2 & 41.429 & 30.469 & .000 & .517 \\
\hline Intercept & 98.119 & 1 & 98.119 & 71.726 & .000 & .557 \\
\hline pre & 56.693 & 1 & 56.693 & 41.443 & .000 & .421 \\
\hline group & 22.967 & 1 & 22.967 & 16.789 & .000 & .228 \\
\hline Error & 77.974 & 57 & 1.368 & & & \\
\hline Total & 5768.000 & 60 & & & & \\
\hline Corrected Total & 161.333 & 59 & & & & \\
\hline
\end{tabular}

a. R Squared $=.517$ (Adjusted R Squared $=.500$ 
After controlling for pre-test, there was a significant difference between the two groups' performance $\mathrm{F}(1,29)=16.78, \mathrm{p}<.05$. The experimental group outperformed on the posttest, compared to the control one (see Table 1 above).

Implementing the pedagogical intervention, that is backward summary technique, led to improved performance on the post-test. The experimental group members were able to infer the authors' meaning, find the main idea, and understand paraphrased sentences on the reading comprehension test. Furthermore, all of them finished the test before the allotted time was over; this was not the case with the control group members.

The covariate, in the pre-test, was significantly related to the participants' reading comprehension F $(1,29)=41.44, \mathrm{p}<.05$. Consequently, it should have been considered as the covariate; otherwise, it would have a negative effect on the effectiveness of the pedagogical intervention.

Finally, the partial effect size, which gives an indication of the magnitude of the effect in the population at large, is .228 , which is moderate. Therefore, it can be claimed that backward summary technique can be an effective way to enhance the reading comprehension skills of students in non-English majors.

To sum up, it can be concluded that the pedagogical intervention, that is backward summary, has a statistically significant effect on reading comprehension enhancement of microbiology majors, while controlling for the effect of the pre-test.

The same procedures were followed with the two nursing experimental and control groups. Table 3 illustrates the results for nursing majors.

Table 3. ANCOVA Results for Nursing Groups

\begin{tabular}{|l|c|c|c|c|c|c|}
\hline \multicolumn{1}{|c|}{ Source } & $\begin{array}{c}\text { Type III Sum } \\
\text { of Squares }\end{array}$ & df & $\begin{array}{c}\text { Mean } \\
\text { Square }\end{array}$ & F & Sig. & $\begin{array}{c}\text { Partial Eta } \\
\text { Squared }\end{array}$ \\
\hline Corrected Model & $172.857 \mathrm{a}$ & 2 & 86.429 & 41.349 & .000 & .592 \\
\hline Intercept & 280.600 & 1 & 280.600 & 134.244 & .000 & .702 \\
\hline pre & 19.257 & 1 & 19.257 & 9.213 & .004 & .139 \\
\hline group & 155.345 & 1 & 155.345 & 74.320 & .000 & .566 \\
\hline Error & 119.143 & 57 & 2.090 & & & \\
\hline Total & 8932.000 & 60 & & & & \\
\hline Corrected Total & 292.000 & 59 & & & & \\
\hline
\end{tabular}

a. R Squared $=.592($ Adjusted R Squared $=.578)$ 
Samaneh Bahrami,

Ramin Rahimy

As Table 3 indicates $F(1,29)=74.32, \mathrm{p}<.05$., so the two nursing groups are different regarding their post-test scores.

As far as the covariate is concerned $\mathrm{F}(1,29)=9.213, \mathrm{p}<.05$, indicating a significant effect for nursing majors. The partial effect size is .566, which is a moderate effect. Consequently, the pedagogical treatment, that is backward summary, seemed to improve the reading comprehension skills of the nursing majors as well.

The experimental group outperformed the control one on their reading post-test. They performed better in detecting main ideas, distinguishing them from details, and inferring the writers' intended meaning compared to the control group. Similar to the students of microbiology majors, the nursing experimental group finished the test before the allotted exam time was over.

Based on the observed results from both microbiology and nursing experimental groups, it can be claimed that backward summary can foster reading comprehension of Iranian nonEnglish majors.

\section{Discussion}

The current study was intended to investigate whether implementing backward summary technique had a positive effect on fostering reading comprehension skills of non-English major university students at the Islamic Azad University of Babol, in the North of Iran.

The first finding of the study was the effectiveness of the pedagogical intervention. Based on the ANCOVA results, both nursing and microbiology experimental groups outperformed their equivalent control groups on the post-test. This is in line with the previous studies which reported positive effects of strategy training on reading comprehension enhancement (Alsamadani, 2011; Fan, 2010; Lin \& Chern, 2014; Khaki, 2014; Mikulecky, 2008; Neufeld, 2005). It was also revealed that using visual outlines can help students organize and categorize ideas, identify main ideas and distinguish them from supporting details, which can lead to improved comprehension and retention of the reading material. This finding is also in parallel with the existing research by Bogoya (2011), Gallavan and Kottler (2007), and

166 Rumiris (2014).

Furthermore, the outcomes are in accordance with a number of previous studies that reported positive effects of summarization (Baleghizadeh \& Babapur, 2011; Caccamise, 2011; Chiu, 2015; Hemmati \& Kashi, 2013; Maybodi \& Maibodi, 2017; Mohammad Hoseinpur, 2015; Pakzadian \& Eslami Rasekh, 2012), together with source-based writing (Grabe \& Zhang, 2013; Hirvela, 2016; Li, 2014; Mokeddem \& Houcine, 2016) in boosting reading comprehension, especially in EFL academic contexts. 
This study added to the existing positive view of the effectiveness of using input tables to create visual outlines at the pre-reading stage to boost comprehension and retention in an academic EFL context. The visual outline paved the way towards more purposeful reading, discovery learning, self-monitoring of comprehension, and handling misunderstanding without the need to resort to mental translation, better understanding, and recall of the read materials.

Visual representation techniques are flexible; they can be used at different stages of the reading comprehension process and should not be limited only to final comprehension check tasks. The study echoes Wormeli's (2005) view about the flexibility and diversity of summarization forms and techniques who argues, "even though it's a good way to end a lesson, it's not just for the end of lessons" (p. 4) and encourages teachers to "use summarization to pre-assess students before teaching them and use students' response to inform and change [their] instruction" (Wormeli, 2005, p. 4).

Before implementing the pedagogical treatment, both nursing and microbiology majors were not eager to read in English because it was demanding, time-consuming, frustrating, and they had problems organizing their ideas, and recalling and restating the gist of what had been read in English. As a result, they resorted to mental translation to ease the mental burden and had no idea how to differentiate the key concepts from details or redundant points. However, using visual outlines changed the whole situation in an amazing way. It helped them to represent the relationship between the main and supporting ideas, displaying instead of expressing in words, and the hierarchical structure of expository texts was revealed to them. Furthermore, they learned how to use the technique to break sentences into meaningful chunks and focus on key concepts. This led to a better command of both reading and writing skills, which are central to academic competency.

It is impossible to survive in academia without having mastery over reading comprehension and source-based writing skills. Visual outlines are effective tools to organize thoughts and merge reading and writing. Finding effective ways to strengthen the bond between these interrelated skills should be a lifetime quest for mindful instruction, which can lead to critical thinking and meaningful learning, two essential life skills for twenty-firstcentury global citizens.

Teachers should bear in mind that for gaining utmost results, reading comprehension strategies must be instructed explicitly and step by step with the aim of turning struggling readers into enthusiastic, strategic, and independent ones. They should play the role of an educator by creating a supportive, stress-free atmosphere, and by encouraging struggling students to share their views without the fear of making mistakes and being judged or criticized for having difficulty in expressing themselves in English. 
Samaneh Bahrami,

Ramin Rahimy

Scaffolding is the best way to increase learners' self-confidence and mastery in reading comprehension and retention. Teachers can also perform as an educator by using the thinking aloud technique and giving live examples of strategy use by modeling the whole process. As a result, their role can be faded gradually, and internalizing the use of the learnt technique can lead to forming a new empowering habit to change stressful and struggling learners into confident, strategic, and self-sufficient ones, willing to read for attaining knowledge and pleasure.

To sum up, students should be told about when and how to use the techniques and why to use them. Finally, teachers should accompany their struggling students through the journey to become strategic, self-regulated, and fully competent learners with patience, understanding, constant encouragement, and support.

\section{Conclusion and Implications}

The current study was an attempt to probe the effect of the backward summary technique in fostering reading comprehension among Iranian nursing and microbiology majors at the Islamic Azad University of Babol in the North of Iran. The students got familiar with the structure of the expository text with the help of visual presentation. They were also able to distinguish main ideas from supporting details or irrelevant information and organize their thoughts by forming mental maps and visual outlines. Expressing the gist in the form of a written summary helped them to recall and restate what they had read without resorting to mental translation. Using pre-reading questions, input tables as visual outlines, and forming while-reading mental maps and writing brief summaries as a follow-up task led to a better understanding and recall of the read materials.

In the globalization era, with an increasing understanding of the importance of becoming competent readers in English, especially in academia, in McDougald and Alvarez-Ayure's (2020) words, "educational programs have to prepare society for jobs, careers, and skill sets that do not exist yet but which lead to shifts in society that are shaped by both the economy and fast-increasing technology at hand throughout the world" (p. 156). Thus, new horizons are ahead for those who can understand and communicate in English, the global language in 168 today's world. Consequently, comprehension strategy training is an essential and inseparable part of any twenty-first century successful and insightful teaching, which advocates discovery learning, self-regulation, lifelong learning, and strategic, autonomous learners.

Pedagogically speaking, strategic teaching can be beneficial for both EFL teachers and struggling learners dealing with the demanding academic reading and source-based writing tasks. Moreover, a greater emphasis on the reciprocal relation between reading and writing may hopefully provoke the substitution of the traditional way of teaching reading and 
writing as separate language skills with more integrated methods at all levels, specifically in EFL academic contexts.

Finally, certain limitations appeared in conducting the current study, due to lack of time and facilities, which should be addressed by further investigation. Firstly, the only available option for the researchers was using intact classes. Therefore, the participants were selected based on their convenience and availability and their inclusion was not randomized. Secondly, only two non-major English groups, including nursing and microbiology freshmen, were chosen to participate in the study. The participants were also limited only to the students who enrolled in the compulsory General English course during the first semester of 2017 at a university. Therefore, the findings may not be applicable to all the non-English major students, elsewhere.

Furthermore, immediately after the end of the treatment, the participants in the present study were tested on their reading comprehension to determine the effects of backward summary technique, used as the instructional intervention. Since final exams were held soon after, and summer term classes were not compulsory, the participants were not available, so the researchers did not have the opportunity to have a delayed post-test. Future research should therefore use a delayed post-test to investigate the long-term effects of the pedagogical treatment and retention of what they have learned from a text by using the technique.

Due to the already-mentioned limitations, the findings of the current study should be seen with caution for making generalizations about effects of backward summary technique on boosting reading comprehension of non-English major university students. Further research with diverse learner groups and levels is undoubtedly required to get to a wider scope on the issue.

\section{References}

Alderson, J. C. (2000). Assessing reading. Cambridge University Press.

Alsamadani, A. H. (2011). The effects of the 3-2-1 reading strategy on EFL reading comprehension. English Language Teaching, 4(3), 184-191. https://doi.org/10.5539/elt.v4np184

Baleghizadeh, S., \& Babapur, M. (2011). The effect of summary writing on reading comprehension and recall of EFL students. New England Reading Association Journal, 47(1), 44-57. https:/ / doi.org/10.5296/jse.v3i2.2644

Bernhardt, E. B. (2011). Understanding advanced second-language reading. Routledge.

Bogoya, A. (2011). Fostering fifth graders' reading comprehension through the use of intensive reading in physical science. Colombian Applied Linguistics Journal, 13(1), 39-57. https://doi. org/10.14483/22487085.2930 
Samaneh Bahrami,

Ramin Rahimy

Caccamise, D. (2011). Improved reading comprehension by writing. Perspectives on Language Learning and Education, 18 (1), 27-3. https:// doi.org/10.1044/1le18.1.27

Chiu, C. (2015). Enhancing reading comprehension and summarization abilities of EFL learners through online summarization practice. Journal of Language Teaching and Learning 1, 79-95. https://dergipark.org.tr/en/pub/jltl/issue/22502/240578

Cook, V. (2008). Second language learning and language teaching. Oxford University Press.

Fan, Y. (2010). The effect of comprehension strategy instruction on EFL learners' reading comprehension. Asian Social Science, 6(8), 19-29. https://.doi.org /987654321/10430

Gallavan, N. P., \& Kottler, E. (2007). Eight types of graphic organizers for empowering social studies students and teacher. The Social Studies, 98, 117-123. https://.doi.org/10.3200/ TSSS.98.3.117-128

Grabe, W. (2009). Reading in a second language: Moving from theory to practice. Cambridge University Press.

Grabe, W., \& Stoller, L., F. (2011). Teaching and researching reading. Routledge.

Grabe, W., \& Zhang, C. (2013). Second language reading-writing relations. In A. S. Horning \& E. W. Kreamer (Eds). Reconnecting reading and writing (pp. 108-133). Parlor Press and WAC Clearinghouse.

Hellman, A. W., Blair, T. R., \& Rupley, W. H. (1998). Principles and practices of teaching reading (9 $9^{\text {th }}$ ed.). Merrill.

Hemmati, F., \& Kashi, M. (2013). The impact of oral retelling and summary writing techniques on Iranian upper intermediate EFL learners' reading comprehension. International Journal of English and Education, 2(2).42-61. https://.doi.org/ijee.0rg/5.89113136

Hirvela, A. (2016). Connecting reading and writing in second language writing instruction. University of Michigan.

Khaki, N. (2014). Improving reading comprehension in a foreign language: Strategic reader. The Reading Matrix, 14(2), 186- 200. https://.doi.org/11-m9371u67.pdf

Koda, K. (2005). Insights into second language reading: A cross-linguistic approach. Cambridge University Press.

Li, J. (2014). The role of reading and writing in summarization as an integrated task. Language Testing in Asia, 4(3), 1-19. https:// doi.org/10.1186/2229-0443-4-3

Lin, H. Y., \& Chern, L. C. (2014). The effects of background knowledge and L2 reading proficiency on Taiwanese university students' summarization performance. Contemporary Educational Research Quarterly, 22(4), 149-186. https://.doi.org/10.6151/CERQ.2014.2204.04

Maybodi, A., \& Maibodi, A. (2017). The effect of teaching summarization strategies on reading comprehension of science and humanities Iranian high school students. Indonesian Journal of EFL and Linguistics, 2(1), 41-52. https:/ /.doi.org/27-144-1-PB.pdf 
McDougald, J. S., \& Álvarez-Ayure, C. P. (2020). Expanding the value of CLIL: Perspectives from primary to higher education. Latin American Journal of Content \& Language Integrated Learning, 13(2), 155-162. https://doi.org/10.5294/laclil.2020.13.2.1

Meyen, E. L., Vergason, G. A., \& Whelan, R. J. (1996). Strategies for teaching exceptional children in inclusive setting. Love.

Mikulecky, B. S. (2008). Teaching reading in a second language. Pearson.

Mohammad Hoseinpur, R. (2015). The impact of teaching summarizing on EFL learners' microgenetic development of summary writing. The Journal of Teaching Language Skills (JTLS), $34(2), 69-92$.

Mokeddem, S., \& Houcine, S. (2016). Exploring the relationship between summary writing ability and reading comprehension: Toward an EFL writing-to-read instruction. Mediterranean Journal of Social Sciences MCSER, 7(2), 197-205. https://.doi.org/10.5901/mjss.2016. v7n2s1p197

Neufeld, P. (2005). Comprehension instruction in content area classes. International Reading Association, 302-312. https://.doi.org/ 10.1598/RT.59.4.1

Pakzadian, M., \& Eslami Rasekh, A. (2012). The effects of using summarization strategies on Iranian EFL learners' reading comprehension. English Language Research, 1(1), 118-125. https:/ / . doi.org/10.5430/elr.vlnlp11

Pardo, S. L. (2004). What every teacher needs to know about comprehension. International Reading Association, 272- 280. https://doi.org/10.1598/RT 58.3.5

Pressley, M. (2006). Reading instruction that works: The case for balanced teaching ( $3^{\text {rd }}$ ed.). The Guilford Press.

Robson, C. (1993). Real world research: A resource for social scientist and Practitioner researcher. Blackwell.

Rumiris, J. (2014). Improving university students' reading comprehension using graphic organizers: An action research. Jurnal Dinamika Pendidikan, 7(3), 157-164. https//www.http:/ / journal.uki.ac.id

Shokrpour, N., Sadeghi, A., \& Seddigh, F. (2013). The effect of summary writing as a critical reading strategy on reading comprehension of Iranian EFL learners. Journal of Studies in Education, 3 (2), 127-138. https://doi.org/10.5296

Smith, F. (2004). Understanding reading: A psycholinguistic analysis of reading and learning (6 $6^{\text {th }}$ ed.). Lawrence Erlbaum.

Tarshaei, G., \& Karbalaei, A. (2015). The effect of three phase approach on Iranian EFL learners' reading comprehension. European Online Journal of Natural and Social Sciences, 4(2), 362-372. https://www.core.ac.uk

Westby, C., Culatta, B., Lawrence, B., \& Hall-Kenyon, K. (2010). Summarizing expository texts. Topics in Language Disorders, 30(4). 275-87.

Wilhelm, K., \& Li, H. (2008). Exploring pedagogical reasoning: Reading strategy instruction from two teachers' perspectives. The Reading Matrix, 8(1) 96-110. https://.doi.org/10.1.1.579.9383 
Samaneh Bahrami,

Ramin Rahimy

Wormeli, R. (2005). Summerization in any subject: 50 techniques to improve student reading. The Association for Supervision and Curriculum Design (ASCD).

Zahedi, Z., \& Tabatabaei, O. (2015). The effect of blended teaching on reading strategy use by Iranian EFL learners. International Journal of Foreign Language Teaching \& Research, 3(11), 25- 38. https://www.iaun.ac.ir 